\title{
Implementasi Silase Kulit Buah Kakao dan Zinc-Metionin pada Ransum Kambing Boerka di Kabupaten Pidie Jaya
}

\section{(Implementation of Cocoa Pod Silage and Zinc-Methionine in Diet for Boerka Goat in District Pidie Jaya)}

\author{
Yusriani $\mathrm{Y}^{1}$, Puastuti $\mathrm{W}^{2}$ \\ ${ }^{1}$ Balai Pengkajian Teknologi Pertanian Aceh \\ ${ }^{2}$ Balai Penelitian Ternak \\ yenniyusriani@ymail.com
}

\begin{abstract}
The use of cocoa pod (CP) as feed in the cocoa-livestock integration system was done in Pidie Jaya District. This study aimed to evaluate the use of CP silage with zinc-methionine supplementation as a substitute for grass to improve the performance of Boerka goats. A number of 24 Boerka goats with a weight of $23.4 \pm 3.1 \mathrm{~kg}$ aged $7-8$ months were used in the study of 3 types of rations, namely R1, native grass + concentrate; R2, CP silage + concentrate; R3, CP silage + concentrate + zinc-methionine. The ration was given for 4 months. The study was conducted using a randomized design with 8 replicates per each treatment. The results of the study showed that $\mathrm{CP}$ silage had nutrient composition equivalent to native grass. Boerka goats of $\mathrm{R} 1$ consume nutrients higher $(\mathrm{P}<0.05)$ than those of $\mathrm{R} 2$ and $\mathrm{R} 3$, but ADG of goats among the three rations is similar $(\mathrm{R} 1=106.9 \pm 41.09 \mathrm{~g} / \mathrm{hd}, \mathrm{R} 2=$ $106.0 \pm 30.38 \mathrm{~g} / \mathrm{hd}$ and $\mathrm{R} 3=118.4 \pm 28.36 \mathrm{~g} / \mathrm{hd})$. The addition of zinc-methionine to CP silage ration resulted in a lower FCR value than those feednative grass $(\mathrm{R} 3=8.2 \pm 1.67$ vs. $\mathrm{R} 1=$ 14.6 \pm 5.12 ). It can be concluded that feeding CP silage with zinc-methionine to Boerka goats was able to replace grass with improved FCR.
\end{abstract}

Key words: Cocoa pod silage, zinc-methionine, goat

\begin{abstract}
ABSTRAK
Pemanfaatan kulit buah kakao (KBK) sebagai pakan pada sistem integrasi kakao-ternak telah dilakukan di Kabupaten Pidie Jaya. Kajian ini bertujuan mengevaluasi penggunaan silase KBK dengan suplementasi zink-metionin sebagai pengganti rumput untuk meningkatkan performa kambing Boerka. Sebanyak 24 ekor kambing Boerka dengan bobot hidup 23,4 $\pm 3,1 \mathrm{~kg}$ berumur 7-8 bulan digunakan dalam pengkajian 3 macam ransum, yaitu $\mathrm{R} 1$, rumput lapang + konsentrat; R2, silase $\mathrm{KBK}$ + konsentrat; R3, silase $\mathrm{KBK}+$ konsentrat + Zink-Metionin. Ransum diberikan selama 12 bulan. Pengkajian dilakukan menggunakan rancangan acak dengan jumlah ulangan 8 . Hasil pengkajian menunjukkan bahwa silase KBK memiliki komposisi nutrien setara dengan rumput. Kambing Boerka mengkonsumsi nutrien dari R1 lebih tinggi $(\mathrm{P}<0,05)$ dari $\mathrm{R} 2$ dan $\mathrm{R} 3$, namun $\mathrm{PBHH}$ kambing diantara ketiga ransum serupa yaitu R1 = 106,9 $\pm 41,09 \mathrm{~g} / \mathrm{e}, \mathrm{R} 2=106,0 \pm 30,38 \mathrm{~g} / \mathrm{e}$ dan $\mathrm{R} 3=118,4 \pm 28,36 \mathrm{~g} / \mathrm{e}$. Penambahan Zink-Metionin pada ransum silase KBK menghasilkan nilai FCR yang lebih rendah dibandingkan ransum rumput lapang $(\mathrm{R} 3=8,2 \pm 1,67$ vs $\mathrm{R} 1=14,6 \pm 5,12)$. Dapat disimpulkan bahwa pemberian silase KBK dengan zink-metionin pada kambing Boerka dapat dilakukan untuk menggantikan pakan rumput dan meningkatkan konversi pakan.
\end{abstract}

Kata kunci: Silase KBK, zink-metionin, kambing 


\section{PENDAHULUAN}

Indonesia merupakan produsen kakao terbesar ke-3 dunia setelah Pantai Gading dan Ghana (Nauly et al. 2014). Perkebunan kakao menempati luas areal terbesar keempat untuk subsektor perkebunan setelah perkebunan kelapa sawit, kelapa dan karet. Selain itu, ekspor komoditas kakao memberikan sumbangan devisa terbesar ketiga setelah ekspor komoditas kelapa sawit dan karet. Prospek pasar kakao dunia juga terus mengalami peningkatan dari tahun ke tahun (Maulana et al. 2017). Luasan perkebunan kakao memberi gambaran terhadap potensi sumber pakan dari hasil sampingnya.

Pengembangan usaha peternakan dengan memanfaatkan hasil samping kulit kakao sebagai pakan ternak melalui pola integrasi tanaman ternak diharapkan mampu mendukung produktivitas baik tanaman maupun ternak sebagai upaya efisiensi usahatani yang sekaligus mampu meningkatkan pendapatan petani di pedesaan. Pola integrasi yang tepat perlu dilihat dari komoditas ternak yang mampu memanfaatkan limbah kulit kakao, serta dengan mudahnya petani dalam mengaplikasikan teknologi tersebut, sehingga mampu mendukung sistem multi usaha (usaha perkebunan dan peternakan). Pola integrasi usaha ternak kambing pada kondisi perkebunan kakao rakyat yang sudah dirintis perlu dikaji prospeknya dalam mendukung pengembangan wilayah di Kabupaten Pidie Jaya, Provinsi Aceh yang merupakan basis pengembangan perkebunan kakao rakyat.

Dalam rangka pengembangan populasi ternak yang berkelanjutan diperlukan dukungan sumber pakan baik kualitas, kuantitas dan kontinuitas. Pemanfaatan kulit buah kakao (KBK) segar sebagai pakan ternak kambing sudah dilakukan di beberapa daerah sentra kakao. Pemberian KBK segar sebagai pakan memiliki palatabilitas tinggi. Penggunaan KBK dalam keadaan segar hanya pada waktu musim panen kakao saja dikarenakan daya simpan KBK tidak lebih dari 3 hari jika sudah dipisahkan dari bijinya (Puastuti \& Yulistiani 2011). Biomasa KBK memiliki komposisi nutrien yang cukup baik sebagai bahan pakan, namun kecernaan KBK sedikit lebih rendah dibandingkan rumput karena adanya lignin dan tanin dan antinutrisi theobromin. Adanya laporan bahwa penggunaan KBK tanpa diolah menurunkan konsumsi bahan kering dan menghasilkan penurunan pertambahan bobot hidup, maka pemanfaatan KBK sebagai pakan perlu diolah terlebih dahulu.

Metode pengolahan KBK sudah banyak dilaporkan. Pengolahan secara fisik (Adamafio et al. 2011), secara kimiawi mampu menurunkan kadar theobromin dari KBK, meningkatkan kecernaan bahan kering (Afrijon 2011; Puastuti et al. 2010; Laconi et al. 2009) dan secara biologis melalui fermentasi oleh Aspergillus niger mampu menurunkan kadar serat kasar, meningkatkan kadar protein dan meningkatkan kecernaan total (Indariyanti \& Rakhmawati 2013), fermentasi oleh Phanerochaeta chrysosporum mampu menurunkan kadar lignin (Suparjo et al. 2011) dan meningkatkan kadar protein kasar (Syahrir et al. 2013). Berbagai metode pengolahan pakan tentu saja memiliki kelebihan dan kekurangan baik secara teknis maupun non teknis. Perlu diupayakan teknologi pemanfaatan KBK sebagai pakan ternak yang murah dan mudah diaplikasikan oleh petani peternak, salah satunya dengan pengolahan secara silase. Untuk mengoptimalkan pemanfaatan KBK yang mengandung serat kasar tinggi diperlukan suplemen mineral yang mampu meningkatkan kecernaannya. Penambahan mineral Zn-metionin dalam pakan dapat meningkatkan kecernaan komponen serat kasar secara in vitro (Supriyati 2008). Puchala et al. (1999) melaporkan Peningkatan BH untuk kambing yang mendapatkan suplementasi $\mathrm{Zn}$ anorganik $(\mathrm{ZnO})$ lebih rendah daripada kambing yang diberi suplementasi Zn metionin (50,5 vs $67 \mathrm{~g} / \mathrm{hari}$ ). Devi et al. (2011) menambahkan Zn 
organik pada kambing jantan lokal ternyata $\mathrm{PBHH}$ lebih besar dibandingkan dengan $\mathrm{Zn}$ anorganik.

Respon penggunaan KBK sebagai pakan menghasilkan respon positif terhadap peningkatan bobot hidup, diantaranya pada ternak domba (Zain 2009; Puastuti et al. 2010), pada kambing (Suparjo et al. 2011; Puastuti \& Yulistiani 2011) dan pada sapi (Laconi 2009). Berdasarkan tinjauan tersebut, penelitian ini bertujuan mengkaji penggunaan silase KBK sebagai pengganti rumput dengan suplementasi mineral zink metionin untuk meningkatkan performa kambing Peranakan Boerka.

\section{MATERI DAN METODE}

\section{Materi pakan, ternak dan perlakuan}

Kulit buah kakao (KBK) dikumpulkan dari lokasi di sekitar kandang pengkajian milik peternak di Pidie Jaya. Kulit buah kakao segar yang dikumpulkan dibuat silase mengikuti metode Puastuti \& Yulistiani (2011). Kulit buah kakao segar dicacah dan ditambah dedak padi sebanyak 5\% dari bahan segar KBK dan disimpan dalam kantong plastik tertutup (anaerob) selama 21 hari. Silase KBK diberikan pada kambing dalam keadaan segar. Pakan perlakuan yang dikaji adalah:

$\mathrm{R} 1$, Pakan rumput + konsentrat;

R2, Pakan silase KBK + konsentrat;

R3, Pakan silase KBK + konsentrat + mineral zink-metionin.

Rasio pemberian rumput/silase KBK dan konsentrat sebesar 50: 50. Konsentrat disusun dari bahan sebagai berikut: dedak padi, jagung giling kasar, bungkil inti sawit (BIS), bungkil kedelai, onggok, molasses dan urea dengan kandungan protein 16,14\%, lemak 5,07\%, dan energi GE 3468,98 kkal/kg. Suplemen zink-metionin diberikan sebanyak $50 \mathrm{mg}$ per $\mathrm{kg}$ bahan kering konsentrat. Zink-metionin yang digunakan diproduksi di Balitnak. Pakan rumput segar dan konsentrat atau silase KBK dan konsentrat diberikan secara terpisah pada pagi dan sore hari.

Digunakan 24 ekor kambing Boerka dengan bobot hidup 23,4 $\pm 3,1 \mathrm{~kg}$ dan umur 7- 8 bulan. Ternak di tempatkan pada kandang individu yang dilengkapi tempat pakan dan minum. Pakan perlakuan diberikan selama 4 bulan, dengan masa adaptasi selama 2 minggu. Konsumsi pakan diketahui dengan mengukur jumlah pakan yang diberikan dan sisa. Pengukuran bobot hidup dilakukan setiap minggu sebelum ternak diberi pakan.

\section{Metode analisis}

Pengkajian dilakukan menggunakan rancangan acak kelompok berdasarkan bobot hidup untuk 3 perlakuan ransum dengan pengulangan sebanyak 8 kali. Data yang terkumpul dianalisis sidik ragam dan dilakukan uji perbedaan nilai dengan menggunakan Duncan Test.

\section{HASIL DAN PEMBAHASAN}

\section{Silase KBK dan rumput}

Pada Tabel 1 disajikan hasil analisis biomasa KBK, silase KBK dan rumput lapang. Biomasa KBK memiliki komposisi nutrien yang setara dengan rumput lapang. Hal ini sesuai informasi sebelumnya bahwa biomasa KBK mengandung 6,8-10\% protein kasar, 
1,6-2,4\% lemak, 24-35\% serat kasar dan $2.600 \mathrm{Kkal} / \mathrm{kg}$ energi (Adamafio 2013) dan $3.900 \mathrm{Kkal} / \mathrm{kg}$ energi (Puastuti \& Yulistiani 2011) yang sebanding dan bahkan lebih baik dibandingkan dengan rumput gajah yang memiliki komposisi 6,9\% protein kasar, 67,09\% serat deterjen netral dan 47,16\% serat deterjen asam (Puastuti \& Yulistiani 2011; Supriyati et al. 2015). Kadar lignin dan tanin KBK berturut-turut 20,15\% (Zain 2009) dan 5,1\% (Mensah et al. 2012) dan theobromin 0,15-0,40\% (Adamafio 2013).

Adanya laporan bahwa penggunaan KBK tanpa diolah pada domba dan kambing menurunkan konsumsi bahan kering dan menghasilkan penurunan pertambahan bobot hidup karena adanya antinutrisi theobromin (Alexander et al. 2008). Berdasarkan informasi tersebut maka, untuk meningkatkan kecernaan KBK, menurunkan antinutrisi dan meningkatkan daya cernanya perlu dilakukan pengolahan. Pengolahan secara silase dapat dilakukan dengan memanfaatkan mikroba alami penghasil asam laktat tanpa atau dengan tambahan sumber karbohidrat mampu mempertahankan kualitas bahan dan meningkatkan daya simpan (Puastuti \& Susana 2014).

Tabel 1. Komposisi nutrien silase KBK vs rumput lapang

\begin{tabular}{|c|c|c|c|c|c|c|c|c|}
\hline \multirow{2}{*}{ Uraian } & BK & Protein & NDF & $\mathrm{ADF}$ & Lignin & $\mathrm{Ca}$ & $\mathrm{P}$ & \multirow{2}{*}{$\frac{\mathrm{GE}}{\mathrm{Kkal} / \mathrm{Kg}}$} \\
\hline & \multicolumn{7}{|c|}{ - } & \\
\hline $\begin{array}{l}\text { Rumput } \\
\text { lapang }\end{array}$ & 29,82 & 9,56 & 69,19 & 51,71 & 8,61 & 0,46 & 0,31 & 3.910 \\
\hline KBK & 20,04 & 9,03 & 72,58 & 61,32 & 29,53 & 0,45 & 0,21 & 4.139 \\
\hline $\begin{array}{l}\text { Silase } \\
\text { KBK }\end{array}$ & 23,63 & 9,28 & 72,11 & 61,18 & 26,38 & 0,34 & 0,29 & 4.030 \\
\hline
\end{tabular}

Sumber: Laboratorium Balitnak (2016)

Hal ini sesuai pernyataan Puastuti et al. (2011) bahwa biomasa KBK yang disilase dapat disimpan hingga 3-4 bulan. Setelah lebih dari tiga hari KBK segar akan ditumbuhi jamur sehingga menyebabkan KBK tidak palatabel sebagai pakan ternak (Puastuti et al. 2009). Jadi pengolahan dengan cara disilase lebih ditujukan untuk meningkatkan daya simpan. Walaupun pengolahan secara silase tidak memberikan perbedaan yang signifikan dalam hal komposisi nutriennya, namun penurunan anti nutrisi memberikan efek yang positif.

\section{Konsumsi nutrien}

Pemberian pakan silase KBK dan suplementasi mineral Zink-Metionin sebagai pengganti rumput menghasilkan konsumsi nutrien yang berbeda-beda (Tabel 2). Konsumsi $\mathrm{BK}$ total tertinggi pada $\mathrm{R} 1$ berbeda nyata $(\mathrm{P}<0,05)$ dengan $\mathrm{R} 2$ dan $\mathrm{R} 3$. Konsumsi pakan berkaitan dengan kecernaan nutrien yang dikandungmya, sedangkan kecernaan dipengaruhi oleh jumlah serta kandungan nutrient yang dikonsumsi oleh ternak tersebut. Besarnya kecernaan menentukan banyaknya nutrien yang dapat dimanfaatkan untuk mem enuhi kebutuhan hidup pokok dan pertumbuhan (Paramita et al. 2008). Dado \& Allen (1995) menyatakan bahwa kecernaan bahan kering sangat nyata dipengaruhi oleh kandungan NDF pakan dimana kandungan NDF yang tinggi memberikan respon yang rendah terhadap kecernaan bahan kering. Kecernaan NDF lebih tinggi pada pakan dengan kandungan serat rendah dibandingkan pakan dengan kandungan serat tinggi. 
Tabel 2. Konsumsi nutrien kambing yang diberi pakan KBK vs rumput

\begin{tabular}{|c|c|c|c|}
\hline Konsumsi: & $\mathrm{R} 1$ & $\mathrm{R} 2$ & R3 \\
\hline \multicolumn{4}{|l|}{$\mathrm{BK}(\mathrm{g} / \mathrm{e})$} \\
\hline Konsentrat & $600,2 \pm 79,2^{\mathrm{a}}$ & $558,9 \pm 46,6^{\mathrm{b}}$ & $508,4 \pm 65,4^{\mathrm{c}}$ \\
\hline Rumput/silase & $787,3 \pm 122,1^{\mathrm{a}}$ & $456,6 \pm 50,8^{\mathrm{b}}$ & $431,0 \pm 69,3^{\mathrm{b}}$ \\
\hline Total & $1387,5 \pm 201,3^{\mathrm{a}}$ & $1015,5 \pm 97,2^{b}$ & $939,4 \pm 134,7^{\mathrm{c}}$ \\
\hline \multicolumn{4}{|l|}{ PK (g/e) } \\
\hline Konsentrat & $102,6 \pm 13,5^{\mathrm{a}}$ & $95,6 \pm 8,0^{\mathrm{b}}$ & $86,8 \pm 11,2^{\mathrm{c}}$ \\
\hline Rumput/silase & $38,2 \pm 7,6^{\mathrm{a}}$ & $39,3 \pm 4,5^{\mathrm{a}}$ & $37,0 \pm 12,4^{\mathrm{a}}$ \\
\hline Total & $140,9 \pm 21,1^{\mathrm{a}}$ & $134,9 \pm 12,4^{\mathrm{b}}$ & $123,8 \pm 17,1^{\mathrm{c}}$ \\
\hline \multicolumn{4}{|c|}{ Energi (GE Kkal/e) } \\
\hline Konsentrat & $2721,0 \pm 359,0^{\mathrm{a}}$ & $2533,9 \pm 211,3^{b}$ & $2385,2 \pm 301,6^{\mathrm{c}}$ \\
\hline Rumput/silase & $1761,8 \pm 309,3^{\mathrm{a}}$ & $1779,3 \pm 205,1^{\mathrm{a}}$ & $1648,5 \pm 272,1^{\mathrm{a}}$ \\
\hline Total & $4482,8 \pm 668,0^{\mathrm{a}}$ & $4313 \pm 416,3^{\mathrm{b}}$ & $3987,9 \pm 573,5^{b}$ \\
\hline \multicolumn{4}{|l|}{$\mathrm{NDF}(\mathrm{g} / \mathrm{e})$} \\
\hline Konsentrat & $222,2 \pm 29,3^{\mathrm{a}}$ & $206,97 \pm 17,3^{\mathrm{b}}$ & $180,0 \pm 23,2^{\mathrm{c}}$ \\
\hline Rumput/silase & $316,5 \pm 54,7^{\mathrm{ab}}$ & $338,14 \pm 35,4^{\mathrm{a}}$ & $309,5 \pm 47,6^{\mathrm{b}}$ \\
\hline Total & $538,8 \pm 84,0^{\mathrm{a}}$ & $545,10 \pm 52,6^{\mathrm{a}}$ & $489,5 \pm 70,8^{b}$ \\
\hline \multicolumn{4}{|l|}{$\mathrm{ADF}(\mathrm{g} / \mathrm{e})$} \\
\hline Konsentrat & $142,9 \pm 18,9^{\mathrm{a}}$ & $133,1 \pm 11,1^{\mathrm{b}}$ & $113,6 \pm 14,6^{\mathrm{c}}$ \\
\hline Rumput/silase & $243,5 \pm 40,9^{\mathrm{c}}$ & $299,6 \pm 29,6^{\mathrm{a}}$ & $272,5 \pm 40,2^{b}$ \\
\hline Total & $386,4 \pm 59,7^{\mathrm{b}}$ & $432,7 \pm 40,7^{\mathrm{a}}$ & $386,1 \pm 54,9^{b}$ \\
\hline \multicolumn{4}{|l|}{ Lignin (g/e) } \\
\hline Konsentrat & $36,5 \pm 4,8^{\mathrm{a}}$ & $34,0 \pm 2,8^{\mathrm{b}}$ & $27,4 \pm 3,5^{\mathrm{c}}$ \\
\hline Rumput/silase & $42,2 \pm 6,8^{\mathrm{b}}$ & $151,6 \pm 14,1^{\mathrm{a}}$ & $142,5 \pm 19,3^{\mathrm{a}}$ \\
\hline Total & $78,7 \pm 11,6^{\mathrm{c}}$ & $185,7 \pm 16,9^{\mathrm{a}}$ & $169,9 \pm 22,9^{b}$ \\
\hline
\end{tabular}

Superskrip yang berbeda pada baris yang sama menunjukkan perbedaan yang nyata $(\mathrm{P}<0,05)$

Konsumsi BK rumput lapang lebih tinggi dari konsumsi silase KBK. Keberadaan lignin dan silika yang tinggi pada KBK, juga menyebabkan rendahnya nilai kecernaan (Oluokun 2005), sehingga menyebabkan konsumsi menjadi lebih rendah. Jumlah konsumsi BK yang lebih tinggi sesuai kebutuhan berdasarkan bobot hidup ternak. Kambing yang digunakan pada kelompok perlakuan R1 lebih tinggi dibanding R2 dan R3 (Tabel 3). Konsumsi BK silase pada R2 dan R3 tidak menunjukkan perbedaan. Selaras dengan hasil sebelumnya bahwa pemberian zink-biokomplek pada ransum dengan kandungan protein 14 dan $16 \%$ tidak menghasilkan perbedaan konsumsi BK ransum (Supriyati et al. 2015).

Konsumsi protein yang lebih rendah $(\mathrm{P}<0,05)$ pada $\mathrm{R} 2, \mathrm{R} 3$ dibandingkan $\mathrm{R} 1$ dan konsumsi energi pada R1 dibanding R2 dan R3 (namun keduanya tidak berbeda nyata) mengikuti konsumsi bahan kering total ransum (Tabel 2). Keadaan ini sejalan dengan yang dilaporkan oleh Sultan et al. (2009) bahwa konsumsi protein bahan pakan 
mempunyai korelasi positif dengan jumlah konsumsi bahan kering. Lallo (1996) melaporkan bahwa konsumsi energi meningkat sejalan dengan peningkatan kandungan energi pakan.

Konsumsi serat ADF dan lignin yang tinggi akan meningkatkan aktivitas mengunyah dan energi yang dikeluarkan lebih tinggi dan juga menekan nilai kecernaan pakan. Tetapi penembahan zink dalam bentuk zink metionin akan meningkatkan kecernaan pakan karena zink dibutuhkan oleh bakteri rumen. Konsumsi serat NDF dan ADF dari ransum R2 dan R3 yang lebih tinggi dari R1 sejalan dengan tingginya kadar NDF dan ADF silase KBK sedangkan kandungan NDF pada rumput paling rendah. Demikian juga kandungan lignin pada R2 dan R3 lebih tinggi dibanding R1 disebabkan kandungan lignin rumput paling rendah. Konsumsi lignin yang tinggi terjadi pada R2 dan R3. Konsumsi bahan kering yang rendah disebabkan kandungan fraksi serat yang tinggi. Ditambah lagi bila serat pakan terikat oleh lignin. Kandungan lignin dan tanin dalam KBK yang tinggi telah dilaporkan dapat mempengaruhi kecernaan bahan kering. Lignin yang tinggi dalam ransum berpengaruh terhadap jumlah konsumsi nutriennya. Lignin tersusun atas jaringan polimer fenolik yang berfungsi merekatkan serat selulosa dan hemiselulosa sehingga strukturnya menjadi sangat kuat (Aji et al. 2013). Lu et al. (2005) menjelaskan bahwa kandungan serat sebesar $18 \%$ akan menghasilkan konsumsi bahan kering tertinggi dan menurun pada kandungan serat lebih dari $18 \%$. Konsumsi bahan kering dan karbohidrat bukan serat (non-fiber carbohydrate, NFC) menurun secara linier dengan peningkatan kandungan NDF pakan (Zhao et al. 2011) karena peningkatan konsumsi fraksi serat akan meningkatkan aktivitas mengunyah (Lu et al. 2005).

\section{Pertambahan bobot hidup harian}

Pertambahan bobot hidup harian (PBHH) selama pemberian pakan perlakuan (Tabel 3) menunjukkan perbedaan yang tidak nyata $(\mathrm{P}>0,05)$. Hal ini tidak sejalan dengan konsumsi nutrien yang disajikan pada Tabel 2. Keragaman yang tinggi diantara individu ternak (nilai simpang baku) dalam satu kelompok perlakuan turut mempengaruhi hasil uji perbedaan. Hal ini karena keterbatasan materi yang seragam di lapang. Pola PBHH masing-masing ransum perlakuan (Gambar 1) berfluktuasi setiap minggunya. Adanya pertumbuhan yang negatif R3 minggu ke 2-3 karena ternak sakit sehingga kurva pertumbuhan dimulai dari minggu ke 4 ketika semua ternak dalam keadaan sehat. Pertumbuhan ternak R1 dan R2 cenderung lebih stabil, namun R3 setelah minggu 10 pertumbuhan terus meningkat. Ransum R3 paling tinggi menghasilkan nilai PBHH, walaupun konsumsi nutrien paling rendah (Tabel 2). Perbandingan antara R2 dan R3 menggambarkan bahwa adanya Zink-Metionin memberikan pengaruh terhadap pemanfaatan nutrien dalam tubuh sehingga bisa menghasilkan PBHH yang lebih tinggi. Supriyati et al. (2015) melaporkan bahwa pemberian Zink-biokomplek pada ransum dengan kandungan protein 14 dan 16\% menghasilkan kecernaan BK yang tidak berbeda, namun meningkatkan kecernaan protein dari $56,31 \%$ menjadi $71,19 \%$ pada ransum mengandung protein $14 \%$.

Bila nilai $\mathrm{PBHH}$ dihitung sebagai rasio terhadap rata-rata bobot hidup selama penelitian (PBHH/BH) juga paling tinggi walaupun secara statistik tidak nyata. Perbedaan terlihat bila PBHH dihitung terhadap konsumsi BK. Ransum R3 dengan konsumsi BK paling sedikit dapat dihasilkan nilai konversi pakan yang lebih rendah atau efisiensi yang lebih tinggi $(\mathrm{P}<0,05)$ dari $\mathrm{R} 1$. Domba muda yang disuplementasi Zink organik sebagai Zink proteinat (Kardaya et al. 2001), Zink metionin (Supriyati \& Haryanto 2007) dan Zn biokompleks (Supriyati 2008) pada pakan basal rumput- 
konsentrat meningkatkan PBBH dan memperbaiki rasio konversi pakan (RKP). Haryanto et al. (2005) juga melaporkan bahwa suplementasi $60 \mathrm{mg} \mathrm{Zn/kg}$ sebagai $\mathrm{Zn}$ metionin pada pakan basal jerami padi terfermentasi konsentrat meningkatkan aktivitas mikroba rumen dan Supriyati et al. (2015) melaporkan suplementasi $120 \mathrm{mg} \mathrm{Zn/kg} \mathrm{pada}$ konsentrat $14 \%$ PK memberikan performa lebih baik dibandingkan kontrol tanpa suplemen.

Tabel 3. Pengaruh ransum perlakuan terhadap perubahan bobot hidup

\begin{tabular}{lccc}
\hline \hline Uraian & $\mathrm{R} 1$ & $\mathrm{R} 2$ & $\mathrm{R} 3$ \\
\hline Bobot awal (kg) & $25,5 \pm 2,76$ & $23,4 \pm 2,1$ & $21,0 \pm 2,98$ \\
Bobot akhir (kg) & $35,2 \pm 5,24$ & $33,1 \pm 3,53$ & $31,8 \pm 4,72$ \\
PBHH (g/e) & $106,9 \pm 41,09^{\mathrm{a}}$ & $106,0 \pm 30,38^{\mathrm{a}}$ & $118,4 \pm 28,36^{\mathrm{a}}$ \\
PBHH/BH & $1,4 \pm 0,14^{\mathrm{a}}$ & $1,4 \pm 0,12^{\mathrm{a}}$ & $1,5 \pm 1,12^{\mathrm{a}}$ \\
Konversi pakan & $14,6 \pm 5,12^{\mathrm{a}}$ & $10,3 \pm 3,11^{\mathrm{ab}}$ & $8,2 \pm 1,67^{\mathrm{b}}$ \\
\hline
\end{tabular}

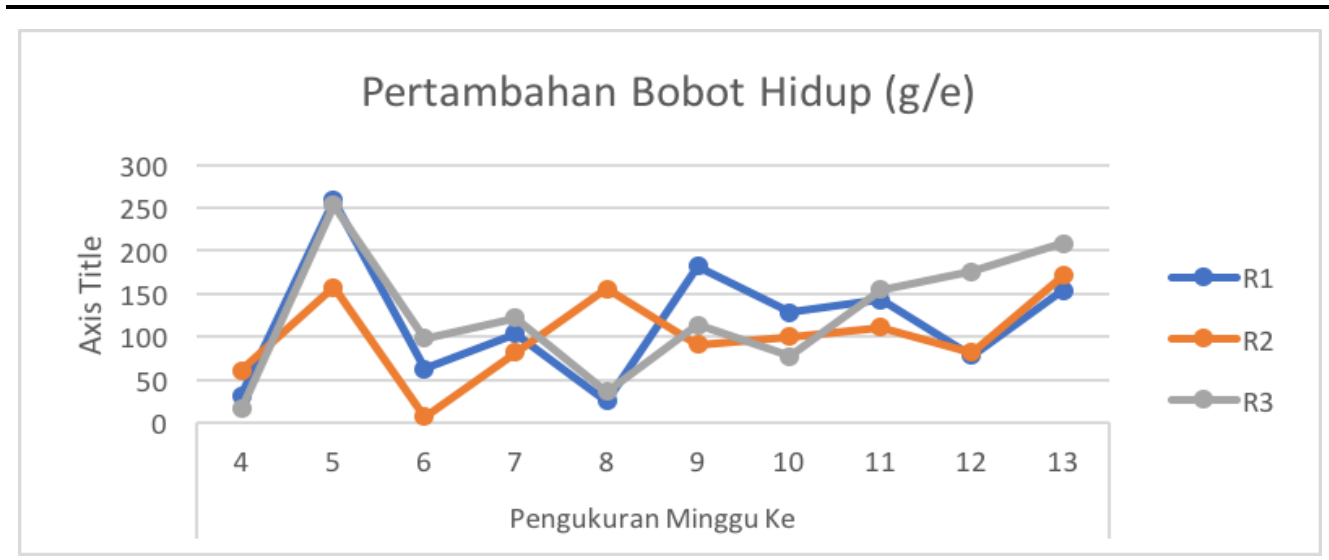

Gambar 1. Pola pertambahan bobot hidup kambing selama percobaan

Proporsi bagian pakan yang hilang dan pemanfaatan lain mempengaruhi efisiensi pakan. Efisiensi pakan dapat diukur dengan efisiensi penggunaan pakan dan konversi pakan. Konversi pakan merupakan jumlah pakan yang dikonsumsi untuk menghasilkan satu unit produksi ternak (Katongole et al. 2009). Nilai konversi pakan yang makin kecil menunjukkan kualitas pakan yang makin baik. Konversi pakan percobaan berkisar 8,214,6. Hasil ini lebih baik dibandingkan konversi KBK pada ternak domba yang berkisar 12,23-17,74 (Lallo 1996). Penelitian Aregoheore (2004) menghasilkan konversi pakan sebesar 14,90 pada ternak kambing yang diberi pakan daun ubi rambat. Besaran nilai konversi pakan sangat tergantung pada kecernaan dan metabolisme nutrisi dalam tubuh ternak. Pakan yang dikonsumsi oleh ternak akan digunakan untuk hidup pokok dan produksi. Konversi pakan perlakuan $\mathrm{R} 1$ lebih besar $(\mathrm{P}<0,05)$ dibanding perlakuan lain. Konversi terkecil $(8,2)$ dicapai oleh perlakuan R3. 


\section{KESIMPULAN}

Silase KBK memiliki komposisi nutrien setara dengan rumput. Pemberian silase KBK dengan zink-metionin pada kambing Boerka dapat menggantikan pakan rumput sekaligus meningkatkan konversi pakan.

\section{UCAPAN TERIMA KASIH}

Penulis mendapat dukungan pendanaan penelitian dari Kementerian Pertanian melalui proyek (KKP3SL) Tahun Anggaran 2016 dengan nomor kontrak: 59.15/PL.040/I.1/03/2016.K tanggal: 14 maret 2016.

\section{DAFTAR PUSTAKA}

Adamafio NA, Ayombil F, Tano-Debrah K. 2011. Microbial detheobromination of cocoa (Theobroma cacao) pod husk. Asian J Biochem. 6:200-207.

Adamafio NA. 2013. Theobromine toxicity and remediation of cocoa by-product: An overview. J Biol Sci. 13:570-576.

Afrijon. 2011. Pengaruh pemakaian urea dalam amoniasi kulit buah coklat terhadap kecernaan bahan kering dan bahan organik secara in-vitro. J Embrio. 4:1-5.

Aji DP, Sri U, Suparwi. 2013. Fermentasi kulit buah kakao (Theobroma cacao L.) menggunakan Aspergillus niger pengaruhnya terhadap kadar VFA dan N-NH3 secara invitro. J Ilmu Peternakan. 1:774-780.

Alexander J, Benford D, Cockburn A, Cravedi J, Dogliotti E, Domenico A Di, Férnandez-cruz ML, Fürst P, Fink-gremmels J, Galli CL, et al. 2008. Theobromine as undesirable substances in animal feed 1 Scientific opinion of the panel on contaminants in the food chain adopted on 10 June 2008. EFSA J. 725:1-66.

Aregheore, E. M. 2004. Nutritive value of sweet potato (Ipomea batatas (L) Lam) forage as goat feed: voluntary intake, growth and digestibility of mixed rations of sweet potato and batiki grass (Ischaemum aristatum var. indicum). Small Rumin Res. 51:235-241.

Dado RG, Allen MS. 1995. intake limitation, feeding behavior, and rumen fungtion of cows challenged with rumen fill from dietary fiber or inert bulk. J Dairy Sci. 78:118-133.

Devi J, Goswami J, Sarmah BC, Chakravarty P, Sarma K. 2011. Effect of zinc supplementation on testicular biometry in Assam local male goat. Indian J Anim Sci. 81:9-11.

Haryanto B, Supriyati, Thalib A, Jarmani SN. 2005. Peningkatan nilai hayati jerami padi melalui bio-proses fermentatif dan penambahan zinc organik. Dalam: Mathius IW, Bahri S, Tarmudji, Prasetyo LH, Triwulaningsih E, Tiesnamurti B, Sendow I, Suhardono, penyunting. Prosiding Seminar Nasional Teknologi Peternakan dan Veteriner. Bogor (Indonesia): Pusat Penelitian dan Pengembangan Peternakan. hlm. 473-478.

Indariyanti N, Rakhmawati. 2013. Peningkatan kualitas nutrisi limbah kulit buah kakao dan daun lamtoro melalui fermentasi sebagai basis protein pakan ikan nila. J Penelitian Pertanian Terapan. 13:108-115.

Kardaya D, Supriyati, Suryahadi, Toharmat T. 2001. Pengaruh suplementasi Zn-proteinat, Cuproteinat dan amonium molibdat terhadap performans domba lokal. Media Peternakan. 24:1-9. 
Katongole CB, Sabiiti EN, Bareeba FB, Ledin I. 2009. Performance of growing indigenous goat fed diet based on urban market crops wastes. Trop Anim Health Prod. 41:329-336.

Laconi EB. 2009. The evaluation of rumen metabolism of Fries Holstein (FH) calves fed biofermented cocoa pods using Phanerochaete chrysosporium. In: Sustainable Animal Production Food Secure Safety 1st International Seminar Animal Industry Faculty of Animal Science. Bogor (Indonesia): Bogor Agricultural University. p. 171-175.

Lallo CHO. 1996. Feed intake and nitrogen utilisation by growing goats fed by-product based diets of different protein and energy levels. Small Rumin Res. 22:193-204.

Lu CD, Kawas JR, Mahgoub OG. 2005. Fiber digestion and utilization in goats. Small Rumin Res. 60:45-65.

Nauly D, Daris E, Nuhung IA. 2014. Daya saing ekspor kakao olahan Indonesia. J Agribisnis. 8:15-28.

Maulana A, Kartiasih F. 2017. Analisis ekspor kakao olahan Indonesia ke sembilan negara tujuan tahun 2000-2014. J Ekonomi Pembangunan Indonesia. 17:103-117.

Mensah CA, Adamafio NA, Amaning-Kwarteng K, Rodrigues FK. 2012. Reduced tannin content of Laccase-treated cocoa (Theobromine cacao) pod husk. Int J Biol Chem. 6:3136.

Oluokun JA. 2005. Intake, digestion and nitrogen balance of diets blended with urea treated and untreated cowpea husk by growing rabbit. Afr J Biotechnol. 4:1203-1208.

Paramita WL, Susanto WE, Yulianto AB. 2008. Konsumsi dan kecernaan bahan kering dan bahan organik dalam haylase pakan lengkap ternak sapi Peranakan Ongole. Media Kedokteran Hewan. 24:59-62.

Puastuti W, Susana IWR. 2014. Potensi dan pemanfaatan kulit buah kakao sebagai pakan alternatif ternak ruminansia. Wartazoa. 24: 151-159.

Puastuti W, Yulistiani D, Mathius IW, Giyai F, Dihansih E. 2010. Ransum berbasis kulit buah kakao yang disuplementasi $\mathrm{Zn}$ organik: Respon pertumbuhan pada domba. JITV. 16:269-277.

Puastuti W, Yulistiani D, Supriyati. 2009. Ransum berbasis kulit buah kakao diperkaya mineral: tinjauan pada kecernaan dan fermentasi rumen in vitro. Dalam: Sani Y, Natalia L, Brahmantiyo B, Puastuti W, Sartika T, Nurhayati, Anggraeni A, Matondang R, Martindah E, Estuningsih SE, penyunting. Teknologi peternakan dan veteriner mendukung industrialisasi sistem pertanian untuk meningkatkan ketahanan pangan dan kesejahteraan peternak. Prosiding Seminar Nasional Teknologi Peternakan dan Veteriner. Bogor (Indonesia): Pusat Penelitian dan Pengembangan Peternakan. p. $442-$ 447.

Puastuti W, Yulistiani D. 2011. Utilization of urea and fish meal in cocoa pod silage based rations to increase the growth of Etawah crossbred goats. In: Ali A, Kamil KA, Alimon AR, Orskov, Zentek J, Tanuwiria UH, editors. Proceeding 2nd International Seminar AINI Feed Safety Health Food. Bandung (Indonesia): Padjadjaran University. p. 463 469.

Puchala R, Sahlu T, Davis JJ. 1999. Effects of zinc methionine on performance of Angora goats. Small Rumin Res. 33:1-8.

Sultan JI, Rahim IN, Yaqoob M, Mustafa MI, Akhtar P. 2009. Nutritional evaluation of herbs as fodder source for ruminant. Pak J Bot. 41:2765-2776.

Suparjo, Wiryawan KG, Laconi EB, Mangunwidjaja D. 2011. Performans kambing yang diberi kulit buah kakao terfermentasi. Media Peternakan. 34:35-41. 
Supriyati. 2008. Pengaruh suplementasi zink-biokompleks dan zink metionat dalam ransom domba. JITV. 13:89-94.

Supriyati, Haryanto B. 2007. Pengaruh suplementasi Zn-biokompleks dalam ransum terhadap pertumbuhan domba muda. JITV. 12:268-273.

Supriyati, Puastuti W, Budiarsana IGM, Sutama I-K. 2015. Effect of protein levels and Zincbiocomplex supplementation in concentrate diets on performance of young male goats. JITV. 20:48-57.

Syahrir H, Kusmartono, Damry. 2013. Effects of cocoa pod husk bioconversion with Phanerochaete chrysosporium and or Pleurotus ostreatus on its nutrient content and invitro digestibility in ruminants. Livest Res Rural Dev [Internet]. 25.

Zain M. 2009. Substitusi rumput lapangan dengan kulit buah coklat amoniasi dalam ransum domba lokal. Media Peternakan. 31:47-52.

Zhao, Zhang XHT, Xu M, Yao JH. 2011. Effects of physically effective fiber on chewing activity, ruminal fermentation, and digestibility in goats. J Anim Sci. 89:501-509. 